\title{
SHAPING A POSITIVE IMAGE OF A HOTEL FACILITY - CORPORATE SOCIAL RESPONSIBILITY APPROACH
}

\section{MARTA SIDORKIEWICZ}

University of Szczecin, POLAND

email: marta.sidorkiewicz@wzieu.pl

\begin{tabular}{|c|c|}
\hline $\begin{array}{l}\text { RECEIVED } \\
\text { ACCEPTED }\end{array}$ & $\begin{array}{l}23 \text { May } 2018 \\
22 \text { September } 2018\end{array}$ \\
\hline $\begin{array}{l}\text { JEL } \\
\text { CLASSIFICATION }\end{array}$ & M37, L83, Z33 \\
\hline KEYWORDS & image, hotel industry, corporate social responsibility \\
\hline ABSTRACT & $\begin{array}{l}\text { The aim of this article is to identify activities undertaken by hotel facilities in order to shape a positive image, } \\
\text { especially in the area of corporate social responsibility (CSR). } \\
\text { The article consists of three content-related parts, as well as introduction and summary. The first and second } \\
\text { part of the article, which are of theoretical character, discuss the essence of shaping the image of a hotel facility } \\
\text { and the theoretical aspects of corporate social responsibility. The third part, which is of empirical character, } \\
\text { presents examples of activities undertaken by hotel facilities in the area of corporate social responsibility. }\end{array}$ \\
\hline
\end{tabular}

\section{Introduction}

In times of intense competition and searching for creative solutions in the area of creation of company image and products, it is a great challenge to achieve recognition in a specific environment. For this reason, modern enterprises are more and more often participating in various activities in the area of corporate social responsibility 
(CSR), which is based on a voluntary act of taking into account ecological and social issues in the company's business activities and relations with their stakeholders.

The aim of this article is to identify activities conducted by hotel facilities in order to shape a positive image, especially in the area of corporate social responsibility (CSR). For the purpose of this article, there was adopted a thesis stating that activities in the scope of corporate social responsibility are an element of shaping a positive image of a hotel facility.

The study employed, in the theoretical part of the article, desk research method, that constitutes a critical analysis of the literature on the subject regarding marketing, hospitality and corporate social responsibility, as well as the analysis of industry reports, available on the Internet (including websites of hotel facilities and their counterparts in social media), in the empirical part of the article.

\section{The essence of shaping an image of a hotel facility}

Today, competition between various companies with the usage of marketing tools, such as a product structure or price, is becoming insufficient due to, among others, financial resources. Therefore, companies such as hotel facilities, which are understood as buildings, complexes of buildings or field devices, whose main aim is to satisfy the basic needs of people living temporarily outside the place of permanent residence, and meeting the requirements for a given type of facility covered by legal provisions, create marketing strategies whose main goal is to create the desired image in the environment. The image reflects the perception of the organization by particular groups from its environment, and thus it is not objective, but a subjective image - a different perception of individual groups operating in the environment (Ćwiklińska, 2012, p. 34).

The elements that build an image include, among others: (Tkaczyk, Rachwalska, 1997, p. 6) name (domain name, trade mark, colouring, etc.), traditions, age, size and scope of action (local, national, international), financial strength and prospects for future development, development mission, product offer, management philosophy, promotion policy, appearance and behaviour of employees, or market conduct. The image is directly related to such factors as identity and reputation, which are sometimes considered equivalent to image. Identity must come before image, which means that the environment must perceive it before the image of the given entity is created (Dziadkiewicz-llkowska, 2010, p. 77).

Image as a marketing category is characterized by performed functions, which are beneficial from the point of view of the supply and demand sides of the market (Altkorn, 2002, p. 5):

- allows effective competition on the market, where entities which have strong and positive image are in particular associated with maximized benefits from the acquirer's point of view,

- positions the entity in the minds of the target audience,

- allows conducting aggressive activities by an entity and achieving desired results,

- lowers promotion costs of new products,

- allows lowering business costs (cooperation),

- provides relatively greater operational stability and less risk.

Due to its complexity, image covers a wide scope of functions (Percy, 2008, p. 62) (also including some benefits), and therefore it might be difficult to include them in their entirety. Image understood as a way of communicating with the environment facilitates the relationship between the parties, as well as makes public opinion loyal to the brand and the entity. Another important factor is that it removes anonymity and allows the creation of a favourable attitude 
towards the entity (e.g. hotel facility). On the other hand, acceptance is an important factor for both the entity and the acquirer, who by acquiring the product satisfy their own need for acceptance (Orfin, Sidorkiewicz, 2016, p. 303).

Therefore, the image of a hotel facility is understood as the way it is perceived by the guests (potential and real), based on the possessed knowledge, information and stimuli. The indicated information and impulses may, to some extent, be controlled by a hotel facility that broadcasts a promotion message to a market (e.g. a country). There are also independent stimuli that are created outside a hotel facility (e.g., opinions of guests and residents, stereotypes) which, in the opinion of the author, may be affected to some extent by an entity coordinating promotional policy of a facility. However, it is a long-term process, which often requires significant changes in a given area.

In the context of searching for a synthetic expression of a hotel facility's image, it can be assumed that the process of building and strengthening image includes such elements as, among others:

- facility localization,

- creativity and innovation in the approach to the offer,

- the culture of handling the process of providing hotel services,

- relationships with guests (clients),

- flexibility in contact with guests,

- quality policy for hotel products.

The proper use of the indicated components constitutes the basis for the creation of a positive image of a given hotel facility.

\section{Theoretical aspects of copporate social responsibility}

The author of the first definition of corporate social responsibility (CSR) is $\mathrm{H}$. Bowen, who defined it in an article from 1953, called "Social Responsibilities of the Businessman", as the obligations of businessmen to pursue those policies, to make those decisions, or to follow those lines of action which are desirable in terms of the objectives and values of our society (Bowen, 1953, p. 6).

In economic terms, corporate social responsibility is defined as an element of company's strategy leading to optimal use of resources based on good relations with the environment and allowing creation of customer loyalty in relation to the company's brand (brands) (Nakonieczna, 2008, p. 20). In 2001, the European Commission defined CSR as "concept whereby companies integrate social and environmental concerns in their business operations and in their interaction with their stakeholders on a voluntary basis". Corporate social responsibility concerns actions by companies over and above their legal obligations towards society and the environment, i.e. also "additional" investment in human capital, environment protection and relationships with the stakeholders. Stakeholders are all persons and institutions interested in successfully achieving the objectives of a specific enterprise. They can be divided into internal stakeholders, such as owners and employees, and external ones that include customers, suppliers, creditors, local community, trade associations, governments of different levels, courts, schools, universities, etc. (Rybak, 2004, pp. 43-50). In 2011, the European Commission added that CSR is "the responsibility of enterprises for their impacts on society". The concept of CSR may be treated as a part of the concept of sustainable development, which underlines the need to properly shape the balance between economic, social and environmental governance. CSR covers actions for sustainable development that the company should undertake (Zielinski, 2014). 
As presented above, there are many definitions of corporate social responsibility in the literature on the subject. Worth mentioning is the fact that these definitions include both economic, legal, sociological as well as ecological and ethical aspects. This undoubtedly demonstrates the complexity of the CSR concept (Leoński, 2014), which is related to the local culture and the degree of development of the country and the industry in which the enterprise operates.

The CSR concept is an important instrument of shaping the future of a company (Wolska, 2014, p. 533) which is related to the benefits that result from the activities carried out by the company in this area (Table 1).

Table 1. The benefits for companies and stakeholders resulting from activities in the area of corporate social responsibility

\begin{tabular}{|c|c|}
\hline Benefits for companies & Benefits for stakeholders \\
\hline $\begin{array}{l}\text { - builds a positive image, } \\
\text { - provides additional advertising (presence in media without incurring } \\
\text { advertising costs), } \\
\text { - facilitates functioning in the local community, } \\
\text { - allows maintaining a high level of loyalty of current customers and } \\
\text { obtaining new ones, } \\
\text { - reinforces the credibility of the mission, } \\
\text { - boosts the effectiveness of activities, } \\
\text { - generates competition on international markets, } \\
\text { - generates an increase in investor interest, } \\
\text { - allows implementation of tax deductions (cash and donations in kind, } \\
\text { help offered by local and central agencies by providing tax reliefs) } \\
\text { which reduces the costs, } \\
\text { - increases employees' satisfaction, } \\
\text { - increases identification of employees with the company, } \\
\text { - affects the positive perception of the company by potential job } \\
\text { candidates, } \\
\text { - positively affects the organization's culture, } \\
\text { - - strengthens credibility, visibility and reputation in the environment }\end{array}$ & $\begin{array}{l}\text { - helps solve social and environmental problems caused by the } \\
\text { company's activity, } \\
\text { - helps companies to be responsible for their actions, } \\
\text { - allows dialogue and partnership with stakeholders, } \\
\text { - CSR programs encourage the company to see wider business } \\
\text { perspectives, } \\
\text { - encourages other companies to use CSR, } \\
\text { - affects social justice, } \\
\text { - helps government and private programs support pro-social and pro- } \\
\text { environmental activities }\end{array}$ \\
\hline
\end{tabular}

Source: own work based on Leoński (2014); Coombs, Holladay (2012), p. 11; Sprinkle, Maines (2010).

When summarizing the concept of CSR, it should be noted that it generates both benefits and costs, as implementation of some activities requires financial as well as human and material capitals. However, taking into account the list of benefits presented, it seems that they exceed the costs associated with its implementation.

\section{Activities in the area of copporgte social responsibility undertaken by hotel facilities - empirical approach}

For the purpose of this study, an analysis of selected websites concerning the hotel industry and websites belonging to hotel facilities was performed. ${ }^{1}$ The collected material allowed the division of activities in the CSR area undertaken by hotel facilities into two groups, i.e. actions for the benefit of ecology and society. Table 2 presents the results of the analysis.

\footnotetext{
${ }^{1}$ The selection of sites is the result of the search on the Internet the following slogans: "hospitality + CSR" and "Hotel + CSR".
} 
Table 2. Practical examples of activities undertaken by hotel facilities in the area of corporate social responsibility

\begin{tabular}{|c|c|}
\hline Types of activities in the area of CSR & Practical examples of undertaken activities \\
\hline Environmental measures & $\begin{array}{l}\text { - reducing energy consumption in the aspect of facility lighting by means of multi-stage brightening and } \\
\text { darkening solutions, together with sensor systems, and access to daylight in conference rooms, } \\
\text { - application of heat recovery ventilation system from air-conditioning, which heats pools and tap water } \\
\text { (the so-called heat recovery), } \\
\text { - installation of air-conditioning equipped with a sensor system that takes into account internal and } \\
\text { external conditions of heat and moisture emission, while automatically controlled heating allows } \\
\text { adjusting the temperature to one's individual needs, } \\
\text { - collection of rainwater, which is used for irrigation of vegetation around the facility, } \\
\text { - reduction of water consumption by installing tap aerators in hotels, which increases the stream } \\
\text { of water through significant aeration, } \\
\text { - use of ecological interior design in the form of, among others, ecological carpeting (the material is } \\
\text { biodegradable and renewable) and furniture made of natural materials (e.g. wood), } \\
\text { - provision of cosmetic services using products that are organic, contain no preservatives and are not } \\
\text { tested on animals, } \\
\text { - use of fresh food supplied from local producers and farmers in the hotel gastronomy, } \\
\text { - removal of dishes containing endangered fish species from the restaurant's menu, } \\
\text { - waste recycling, } \\
\text { - use of renewable energy sources, } \\
\text { - customers are asked to re-use the same towels in order to reduce water and electricity consumption, } \\
\text { - savings obtained from reducing energy consumption are allocated to tree planting }\end{array}$ \\
\hline Pro-social measures & $\begin{array}{l}\text { - participation in charity actions aimed at helping children (for example, putting up a tourist voucher for } \\
\text { an auction), } \\
\text { - active support for local nursing homes, orphanages and animal shelters (blankets, bed sheets, towels, } \\
\text { bathrobes and dishes are given away, and feed and small donations are collected for shelters), } \\
\text { - helping the local community that lost property as a result of a disaster (for example, funding a week's } \\
\text { stay for the victims), } \\
\text { - financial support for sporting events (for example, funding a prize in the form of a stay in the facility for } \\
\text { the winner of local run), } \\
\text { - financial support for sport representatives (e.g. sponsoring a sports team), } \\
\text { - financial and promotional support for local talented artists (e.g. financial support for a cultural centre } \\
\text { or organization of exhibitions on the premises), } \\
\text { - financial support for cultural events (e.g.. "Nowe Horyzonty" festival, "Wratislavia Cantans", } \\
\text { "Międzynarodowy Festiwal Kryminału") } \\
\text { - accepting the "Large Family Card" (granting a rebate for a family stay), } \\
\text { - - fight against sexual abuse of children, involving the mobilization of hotel staff and clients to combat } \\
\text { this problem }\end{array}$ \\
\hline
\end{tabular}

"The Polish "Large Family Card" is a system of discounts for multi-children families. Its holders have the opportunity to use the offer of cultural institutions, recreation centres or transport all over the country.

Source: https://www.arka-mega.pl; https://www.aquariusspa.pl; http://www.delfinhotel.pl; http://www.arthotel.pl; https://www.accorhotels.com; http://www.horecanet.pl/Hotel-wspiera-potrzebujacych,wiadomosc,29,lipiec,2015.aspx.

In order for the activates in the area of CSR, presented in table 2, to constitute factors affecting the positive image of a hotel facility, they have to be popularized. The informative content resulting from the implemented measures is distributed mainly by performing activities in the public relations (PR) area, which is understood as building relations between a given entity and its environment. The essence of PR is striving for good relations with the environment (buyers, shareholders, supervisory boards, suppliers, banks, journalists, social organizations, government agencies) and understanding its activities (Michalski, 2007, p. 370). Therefore, information on activities carried out by a hotel facility for the environment and community are presented in "news" section on the hotel websites and their corresponding social media profiles, speeches, interviews presented in media or industry press. 


\section{Conclusions}

Creating a positive image of a hotel facility in the environment and highlighting its products through activities in the area of CSR may become important factors affecting the growth of competitiveness on the hotel services market. It is worth noting, however, that image creation is a process covering many years, while the effects of undertaken actions are often visible only after a certain period of time.

Although the benefits resulting from involvement in CSR activities are significant, they also generate costs. Therefore, hotel facilities should first and foremost focus on their economic efficiency, which later may be used for the purpose of ecological and social undertakings, as it conditions its financing. Focusing on actions in the area of CSR at the expense of economic efficiency in extreme cases may lead to the decommissioning of a hotel facility. Considering this aspect, hotel facilities should in the first place undertake actions that may prove beneficial (for example, in order to further perform projects with a higher level risk of non-repayment).

\section{References}

Altkorn, J. (2002). Kształtowanie rynkowego wizerunku firmy. Kraków: Wydawnictwo Akademii Ekonomicznej w Krakowie.

Bowen, H. (1953). The Social Responsibilities of Businessman. New York: Harper.

Coombs, W.T., Holladay, S.J. (2012). Managing Corporate Social Responsibility. A Communication Approach. Chichester: Wiley-Blackwell.

Ćwiklińska, J. (2012). Podejmowanie i prowadzenie działalności gospodarczej w turystyce. Część Il-Relacje z otoczeniem. Warszawa: Oficyna Wydawnicza Szkoła Główna Handlowa w Warszawie.

Dziadkiewicz-Ilkowska, A. (2010). Targi jako narzędzie kreowania wizerunku firmy. Toruń: Wyższa Szkoła Bankowa w Toruniu.

http://www.arthotel.pl (24.03.2018).

http://www.delfinhotel.pl (24.03.2018).

http://www.horecanet.pl/Hotel-wspiera-potrzebujacych,wiadomosc,29,lipiec,2015.aspx (24.03.2018).

https://www.accorhotels.com (24.03.2018).

https://www.aquariusspa.pl (24.03.2018).

https://www.arka-mega.pl (24.03.2018).

Leoński, W. (2014). Korzyści i koszty związane ze stosowaniem koncepcji CSR w przedsiębiorstwie. Prace Naukowe Uniwersytetu Ekonomicznego we Wrocławiu, 347, 317-320.

Michalski, E. (2007). Marketing. Podręcznik akademicki. Warszawa: Wydawnictwo Naukowe PWN.

Nakonieczna, J. (2008). Społeczna odpowiedzialność przedsiębiorstw międzynarodowych, Warszawa: Difin.

Orfin, K., Sidorkiewicz, M. (2016). Rola wizerunku krajowego produktu turystycznego w kreowaniu ruchu turystycznego. Studium przypadku na przykładzie Polski i Łotwy. Ekonomiczne Problemy Turystyki, 3 (35), 301-311.

Percy, L. (2008). Strategic Integrated. Marketing Communications. Oxford: Elsevier Inc.

Rybak, M. (2004). Etyka menedżera - społeczna odpowiedzialność przedsiębiorstwa. Warszawa: Wydawnictwo Naukowe PWN.

Sprinkle, G.B., Maines, L.A. (2010). The benefits and costs of corporate social responsibility. Business Horizons, 53, 455-463.

Tkaczyk, J., Rachwalska, J. (1997). Wszystko jest obrazem... Kształtowanie wizerunku przedsiębiorstwa. Marketing i Rynek, 5, 5-10.

Wolska, G. (2014). CSR jako współczesna koncepcja prowadzenia działalności gospodarczej. Zaangażowanie w ideę CSR przedsiębiorstw w Polsce. Prace Naukowe Uniwersytetu Ekonomicznego we Wrocławiu, 347, 533-542.

Zieliński, M. (2014). Koncepcja CSR z perspektywy państwa i przedsiębiorstwa. Prace Naukowe Uniwersytetu Ekonomicznego we Wrocławiu, 347, 552-560.

Cite this article aS: Sidorkiewicz, M. (2018). Shaping a positive image of a hotel facility - corporate social responsibility approach. European Journal of Service Management, 3 (27/1), 263-268. DOI: 10.18276/ejsm.2018.27/1-33. 